\title{
ESTÉTICA AMBIENTAL. IDEIAS, POLÍTICAS E PLANEAMENTO ${ }^{1}$
}

MARGARIDA QUEIRÓs ${ }^{2}$

Da autoria de J. Douglas Porteous, Professor do Departamento de Geografia da Universidade de Victoria, Canadá, Environmental Aesthetics. Ideas, Politics and Planning, revela-se um trabalho inovador e um estudo integrado de uma área interdisciplinar que é a da estética ambiental. Escrito com muita clareza, o livro reúne ideias, métodos e práticas de uma variedade de disciplinas académicas e profissionais.

Passando por temas como a geografia, arquitectura, urbanismo, arte, psicologia e biologia, que contribuem conceptual e empiricamente para o desenvolvimento de uma disciplina nova, Porteous procura um enquadramento comum, enfatizando relações interdisciplinares, para que as ciências humanas e naturais possam, em conjunto, contribuir para a prática do planeamento. Além do mais, o enquadramento teórico sugere a necessidade de uma maior troca de ideias e de informação entre todos os que trabalham em áreas próximas da estética ambiental, no sentido de facilitar a comunicação e de contribuir para um mundo mais agradável do ponto de vista estético.

Os conteúdos discutidos são extraídos da literatura inglesa e de alguma francesa e alemã; consequentemente, este livro traduz a abordagem ocidental à estética ambiental. A Introdução aborda e discute conceitos básicos da estética, a sua história como disciplina desde os tempos medievais aos modernos; apresenta as duas maiores teorias das origens do impulso estético, terminando com uma análise acerca da necessidade de explorar os sentidos através dos quais avaliamos o ambiente. Este capítulo conclui que a identidade dos lugares é multisensorial mas, em alguns casos, uma ou outra percepção sensorial pode ser dominante. Chama a atenção para os modernos ambientes, cuja qualidade e variedade estão rapidamente a ser reduzidos devido à dominância dos veículos motorizados, lembrando que a qualidade sensorial associada ao desenho urbano adequado podem minimizar este problema. Termina o primeiro capítulo dando referências bibliográficas (mencionando trabalhos de historiadores, antropólogos, geógrafos, psicólogos e advogados) para todos os que se interessam pelos assuntos dos cheiros, dos sons e do tacto na análise da paisagem, já que o livro coloca o enfoque na estética visual.

1 Porteous, J. D. (2002) - Environmental Aesthetics. Ideas, Politics and Planning. Routledge, Canada: 290p.

2 Prof. $^{\text {a }}$ Auxiliar do Departamento de Geografia e Investigadora do Centro de Estudos Geográficos da Universidade de Lisboa. E-mail: margaridaq@ceg.ul.pt 
O capítulo seguinte sublinha a abordagem humanista à natureza e à paisagem, passando em revisão a história da estética ambiental no mundo ocidental, procurando relacionar os conceitos históricos de estética com os actuais. A ênfase na abordagem histórica é complementada com a discussão das alterações do gosto pelos diversos tipos de paisagem, tais com as montanhas, o mundo selvagem, jardins e cidades e os contrastes nacionais no gosto pela paisagem no passado e no presente.

O capítulo 3 apresenta a abordagem experimental, quantitativa, em termos do desenvolvimento do interesse da psicologia pela estética e pelo ambiente. As variáveis ambientais e as características dos indivíduos, que com elas interagem, são analisadas. $\mathrm{O}$ autor sublinha que o trabalho das ciências experimentais se revela importante para construir uma ponte entre a intuição humanista e a experimentação, sendo inevitável mais investigação nesta área. Transparece, neste capítulo, a atitude activa dos «experimentalistas» no planeamento da paisagem, posição que implica necessariamente uma neutralidade relativamente aos estímulos do ambiente. Os «activistas» são, porém, tudo menos neutros, como o autor demonstrará no capítulo seguinte.

Muitos dos «activistas» são conservadores com um sentido muito forte de preservação, conservação e de património. Questionam a ética do progresso material subjacente ao capitalismo e estão dispostos a actuar para defender os seus valores: os valores são a base para a acção. O capítulo 4 debruça-se sobre os movimentos radicais relacionados com a estética ambiental, que começam com pequenos grupos (as elites), se difundem pela opinião pública e são suportados por esta. São focados aspectos relacionados com os movimentos de protesto, e as respectivas consequências, na sua grande maioria, responsáveis pela criação de políticas públicas. Os protestos (sobretudo ao nível da literatura e do design) contra os baixos padrões de qualidade estética ambiental são comuns desde o Império Romano. Durante certos períodos, mormente nos séculos XVII e XVIII na Europa, estetas activos assumiram um importante papel na remodelação do countryside e das townscapes no sentido de os moldar aos padrões estéticos da época. A revolução industrial destruiria toda essa preocupação dando primazia às atitudes economicistas. De acordo com o autor, a protecção e a acção pública serão eventualmente mais eficazes se forem introduzidas preocupações com a estética ambiental no planeamento económico e no ordenamento do território; a longo prazo, os interesses do ambiente serão melhor defendidos com acções de educação ambiental.

Durante os finais do século XX, a maioria da população tornou-se urbana. As cidades expandiram-se continuamente e as pressões correspondentes nas áreas rurais tornaram-se idênticas. Não só as cidades devoraram fisicamente os campos como as exigências crescentes em termos de lazer se combinaram com o aumento da mobilidade individual, assegurando que as áreas rurais fossem cada vez mais associadas a áreas de recreio para o urbanita. Além do mais, o impacto da agricultura mecanizada, bem como o abandono das actividades agrícolas, alteraram a forma e a função da paisagem rural, enquanto os estilos arquitectónicos modernistas e pós-modernos transformaram os centros da maior parte das cidades. Por causa destas tendências, com os seus inerentes problemas e conflitos de usos do solo, perda de identidades e distribuição de recursos, as nações ocidentais procuraram, através dos acervos legislativos, proteger a aparência e a integridade das paisagens. $\mathrm{O}$ autor demonstra que qualquer enquadramento legal exige uma racionalidade institucional que depende de conceitos forjados pelos humanistas, repousa sobre as técnicas desenvolvidas pelos «experimentalistas» e é pressionada pelos «activistas».

O capítulo 5 aborda o planeamento da estética ambiental segundo duas componentes: a urbana e a não urbana, replicando a prática corrente no planeamento da 
divisão da abordagem à paisagem rural e à paisagem urbana, enquanto secções separadas. Mesmo se todos os problemas forem resolvidos, o planeamento estético será de pouco valor se o público não se envolver, um objectivo que poderá ser incentivado através da educação ambiental: interpretação, sensibilização, crítica, aprender a «ver». O problema residirá no facto da "extinção da experiência» associada ao rápido declínio da literacia cultural, a par da crescente «teletecnologia» e do desenvolvimento do turismo de massas num mundo global, acentuarem a ideia de que a apreciação estética da paisagem continuará uma prerrogativa de uma elite bem educada.

Por fim, o autor confessa que gostaria que, após a leitura do livro, ninguém ficasse indiferente à estética da paisagem; que as paisagens não sirvam apenas para nosso deleite mas que se tornem conjuntamente o nosso campo de preocupação. 